\title{
ANALISIS KEMAMPUAN KOMPETENSI SOSIAL DALAM PROFESIONALISME PENDIDIK
}

\author{
Aji Sureja ${ }^{1)}$, Santi Hendayani' ${ }^{2)}$, Yesi Budiarti ${ }^{3)}$ \\ ${ }^{1) 2) 3)}$ FKIP, Universitas Muhammadiyah Pringsewu \\ Surel: ajisublegur@gmail.com, santihendayani@umpri.ac.id, yesibudiarti@umpri.ac.id
}

\begin{abstract}
The purpose of this research to describe how the social competence in professional of educators at SDN 1 Sinarmulya, Banyumas District, Pringsewu Regency. The type of research used is qualitative research. The informants used in this study were teachers of grades IV, V, and VI of SDN 1 Sinarmulya, Banyumas District, Pringsewu Regency. Data collection techniques used by researchers are observation and interviews. The technique of cheking the validity of the data is using source triangulation. The results of the study found that teacher at SDN 1 Sinarmulya have good social competence, especially in the indicators of communicating effectively, which are the indicators most mastered by teachers. Teachers at SD N 1 Sinarmulya have good social competence in acting and acting objectively, teachers at SD N 1 Sinarmulya have good social competence in adapting to the environment, teachers at SD N 1 Sinarmulya have good social competence in empathy and courtesy in communicating.
\end{abstract}

Keywords: social competence, professionalism of educators

\section{PENDAHULUAN}

Kompetensi yaitu kemampuan yang dapat dilakukan siswa yang memuat tiga aspek, yakni aspek pengetahuan, sikap, dan keterampilan pembelajaran yang berbasis kompetensi adalah pembelajaran yang memiliki standard. Maka, kompetensi dapat diartikan sebagai suatu ketrampilan, pengetahuan, dan kemampuan yang dimiliki oleh seseorang yang telah menjadi bagian dari dirinya, sehingga ia dapat menerapkan perilaku-perilaku afektif, kognitif, dan psikomotorif dengan sebaik-baiknya. Atau bisa diartikan bahwa kompetensi tidak hanya berisikan pengetahuan, keterampilan dan sikap, akan tetapi yang paling utama adalah penerapan dari pengetahuan, prilaku, dan keterampilan yang diperlukan tersebut dengan seluruh pekerjaan (Syaefudin : 2010). Empat mcam kompetensi yang harus di miliki seorang guru dalam proses belajar mengajar yaitu kompetensi pedagogik, kompetensi kepribadian, kompetensi sosial, dan kompetensi professional. Hal ini di jelaskan dalam Peraturan Menteri Pendidikan Nasional Republik Indonesia Nomor 16 Tahun 2007 tentang standar Kualitas Akademi dan Kompetensi Guru. Untuk menjadi guru professional harus memilki kompetensi 


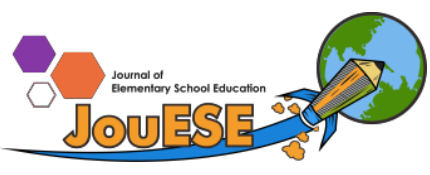

yang memadai agar dapat menjalankan tugasnya seabagai seroang tenaga pendidik dengan baik. Kemampuan mengajar merupakan kemampuan pokok yang wajib dimiliki oleh guru, karena tugas yang paling utama adalah mengajar. Salah satu kompetensi yang dimiliki seorang guru adalah menyangkut kemampuan berkomunikasi dengan peserta didik dengan lingkungan mereka seperti orang tua, tetangga, dan teman sebaya. Kemampuan sosial tersebut dirinci menjadi beberapa aspek, yaitu: bersikap inklusif dan bertindak obyektif, beradaptasi dengan lingkungan tempat bertugas dan dengan lingkungan masyarakat, berkomunikasi secara efektif, empatik dan santun dengan komunitas profesi sendiri maupun profesi lain, secara lisan dan tulisan dalam bentuk lain, serta berkomunikasi secara empirik dan santun dengan masyarakat (Mudlofir: 2012). Bertindak objektif berarti guru juga dituntut berlaku bijaksana, arif, dan adil terhadap peserta didik dalam bertindak, bijak dalam berkata, dan bijak dalam bersikap. Kemudian guru dituntut untuk objektif dalam berkata, objektif dalam berbuat, objektif dalam bersikap, dan objektif dalam menilai hasil belajar. Berkomuikasi dengan efektif yaitu kemampuan guru dalam berkomunikasi dengan baik dan efektif dengan siswa maupun dengan rekan sejawat. Sikap empatik dan santun dapat diaplikasikan dalam cara melakukan kritik, teguran, dan nasehat. Bahasa menjadi solusi alternatif dalam menyampaikan kritik, teguran, dan nasehat tersebut. Bahkan empatik dan santun merupakan cara dan pendekatan yang dilakukan guru dalam melakukan komunikasi dengan anak, sesama kolega, dan masyarakat. Kemampuan beradaptasi dengan lingkungan yaitu kemampuan seorang guru dalam menenmpatkan diri baik dalam proses pembelajaran, lingkungan sekolah maupun lingkungan sekolah. Guru yang memiliki kompetensi sosial, maka hal ini akan diteladani oleh siswa. Sebab dalam pembelajaran guru harus selalu berkomunikasi dengan siswa yang sifatnya membangun proses pembelajaran yang menyenangkan, agar terjadi komunikasi multi arah antara guru dan siswa dalam pembelajaran yang akan menjadikan siswa aktif. Objek dalam penelitian ini yaitu Kemampuan Kompetensi Sosial dalam Profesionalisme Pendidik di SDN 1 Sinamulya yang merupakan salah satu sekolah dasar yang ada di Kabupaten Pringsewu. Berdasarkan observasi yang dilakukan di SDN 1 Sinarmulya peneliti mendapatkan masalah mengenai kompetensi sosial guru pada aspek bersikap dan bertindak objektif yaitu guru kurang mmapu memberikan penilaian secara objektif, 
dikarenakan guru tidak mengetahui secara langsung kondisi apakah tugas yang diberikan oleh guru itu dikerjakan sendiri oleh siswa atau orang tua yang mengerjakan.

Berdasarkan uraian di atas diketahui bahwa guru mengalami kesulitan dalam bertindak onjektif khusunya dalam memberikan penilaian terhadap hasil kerja dari siswa. Kesulitan ini dikarenakan proses pembelajaran dilaksanakan secara daring sehingga seorang guru tidak mengetahui bagaimana kondisi siswa secara langsung sehingga peneliti tertarik untuk meneliti kemampuan kompetensi sosial dalam profesioanlisme pendidik, serta sebagai wawasan untuk calon-calon tenaga pendidik ataupun guru untuk menegtahui bahwa untuk menjadi seorang guru yang professional harus memiliki empat ketrampilan salah satunya yaitu ketampilan sosial atau kemampuan sosial. Penelitian ini berjudul "Analisis Kemampuan Sosial dalam Profesionalisme Pendidik di SDN 1 Sinarmulya”.

\section{METODE PENELITIAN}

Penelitian ini menggunakan metode deskriptif dengan menggunakan pendekatan kualitatif. Analisis data menggunaakan metode deskriptif merupakan analsis data berdasarkan dengan kondisi ilmiah. Metode deskriptif dengan pendekatan kualitatif dalam penelitian ini digunakan untuk mendeskripsikan kemampuan kompetensi sosial guru dalam profesionalisme pendidik di SDN 1 Sinarmulya. Subjek penelitian ini adalah guru kelas IV, V, dan VI di SDN 1 Sinarmulya Kec. Banyumas Kab.Pringsewu. jadi jumlah informan dalam penelitian ini berjumalah 3 orang. Teknik pengumpulan data dalam penelitian ini dilakukan dengan teknik, wawancara, dan dokumentasi. Dokumentasi yang dilakuakn berupa foto atau hasil dari kegiatan belajar mengajar yang dilakukan melalu whatsapp grup. Teknik analisis data dalam penelitian inimenggunakan Triangulasi Sumber.

\section{HASIL DAN PEMBAHSAN}

Dari hasil pengumpulan data yang dilakukan oleh peneliti dengan guru mengenai pelaksanaan kompetensi sosial guru dalam aspek bertindak dan bersikap obyketif diperoleh data bahwa dalam memberikan penilaian terhadap proses dan hasil kerja peserta didik sudah sesuai dengan kemampuan yang dimiliki siswa, tidak menambahkan atau mengurangi. Guru sudah bersikap adil kepada peserta didik 
karena menganggap semua peserta didik sama dan tidak membeda-bedakan ras, agama, ekonomi atau status sosial peserta didik, serta dalam memberikan perhatian tidak pilih kasih. Dalam menangani peserta didik yang melakukan tindakan negatif terhadap peserta didik lain guru selalu memberikan nasihat maupun teguran. Dalam menjaga hubungan baik dengan teman sejawat baik sesama tenaga pendidik maupun kepala sekolah, guru kelas selalu menghargai dan menghormati.

Aspek berkomunikasi secara efektif didapatkan hasil bahwa cara guru dalam menyampaikan pembelajaran agar mudah dipahami adalah dengan menggunakan bahasa lisan dan tulisan yang menarik kepada siswa. Cara guru dalam menampilkan rasa antusias kepada peserta didik agar termotivasi untuk mengikuti pembelajaran yaitu dengan mengajak siswa untuk selalu bertanya saat pembelajaran berlangsung serta memberikan contoh yang menarik. Dalam selalu memberikan kesempatan kepada peserta didik untuk bertanya tentang hal yang belum dipahami setelah pembelajaran selesai Hasil pengumpulan data dengan guru kelas mengenai aspek empatik dan santun dalam berkomnikasi didapatkan hasil bahwa cara guru dalam menasehati siswa adalah dengan suara perlahan dan lemah lembut. Guru selalu memberikan penghargaan terhadap perkembangan peserta didik setelah selesai ujian semester. Guru selalu menunjukan sikap yang lembut terhadap peserta didik baik di sekolah maupun di luar sekolah. Guru menghafal nama-nama orang tua dari masingmasing siswa pada kelas yang diajar. Guru mampu menunjukan sikap terbuka terhadap respon semua peserta didik

Kompetensi sosial guru dalam aspek beradaptasi dengan lingkungan kelas didapat beberapa data yaitu sebelum guru memulai pembelajaran terlebih dahulu mengecek kebersihan kelas, kerapian kelas dan apabila ada sampah maka guru memerintahkan siswa untuk membuangnya ke tong sampah agar kelas terlihat bersih dan nyaman. Selanjutnya, ketika ada siswa yang membuat keributan di kelas maka akan ditegur oleh guru karena siswa tersebut menganggu ketenangan siswa yang lain untuk belajar, hal ini dilakukan agar ketertiban dalam kelas selalu terjaga sehingga suasana kelas menjadi lebih kondusif. Dalam proses pembelajaran di kelas 
guru terkadang juga mengatur tempat duduk siswa agar terlihat rapi. Di samping itu juga, guru memanfatkan lingkungan sebagai sumber belajar dengan cara mengaitkan lingkungan tersebut dengan materi yang diajarkan dan peristiwa yang telah terjadi. Kompetensi sosial merupakan kemampuan pendidik sebagai bagian dari masyarakat untuk berkomunikasi dan bergaul secara efektif dengan peserta didik, sesama pendidik, tenaga kependidikan, orang tua/wali peserta didik, dan masyarakat sekitar. Kemampuan sosial tersebut dirinci menjadi beberapa faktor, yaitu: bersikap inklusif dan bertindak obyektif, beradaptasi dengan lingkungan tempat bertugas dan dengan lingkungan masyarakat, berkomunikasi secara efektif, empatik dan santun dengan komunitas profesi sendiri maupun profesi lain, secara lisan dan tulisan dalam bentuk lain, serta berkomunikasi secara empirik dan santun dengan masyarakat. Hasil penelitian mengenai kompetensi sosial dalam profesionalisme pendidik di SDN1 sinarmulya menunjukan bahwa indikator yang paling dikuasai yaitu berkomunikasi secara efektif. Berkomunikasi secara efektif merupakan kemampuan seorang guru dalam menggunakan bahasa lisan atau tulisan yang mudah dipahami sehingga ketika guru berbicara kepada siswa ataupun menyampaiakan pembelajaran akan mudah di pahamai oleh siswa. Kemudian guru di SD Negeri 1 Sinarmulya memiliki kompetensi sosial yang baik dalam bersikap dan bertindak objektif, guru di SD Negeri 1 Sinarmulya memiliki kompetensi sosial yang baik dalam beradaptasi dengan lingkungan, guru di SD Negeri 1 Sinarmulya memiliki kompetensi sosial yang baik dalam berkomunikasi secara efektif, guru di SD Negeri 1 Sinarmulya memiliki kompetensi sosial yang baik dalam empatik dan santun dalam berkomunikasi

\section{SIMPULAN}

Guru sudah bersikap dan bertindak objektif dalam menilai hasil belajar siswa, mampu memberikan perhatian yang sama kepada semua peserta didik, dan guru juga mampu menjaga hubungan baikm antar rekan sejawat. Guru juga sudah memiliki kompetensi sosial yang baik dalam berkomunikasi secara efektif, hal ini dilihat berdasarkan hasil penelitian bahwa dalam menyampaikan pembelajaran guru menggunakan bahasa yang mudah di pahami, guru juga mampu menunjukan rasa 
antusias kepada peserta didik agar peserta didik termotivasi untuk mengikuti pembelajaran. Empatik dan santun berkomunikasi juga sudah dimiliki oleh guru, baik dalam cara guru menasehati siswa menggunakan bahasa yang santun, memberikan penghargaan terhadap pencapaian peserta didik. Guru juga sudah memiliki kompetensi sosial yang baik dalam beradaptasi dengan lingkungan, karena guru mampu menempatkan diri dengan lingkungan kerja atau lingkungan sekolah dengan baik.

\section{DAFTAR PUSTAKA}

Mudlofir, Ali. (2012). Pendidik Profesional. Jakarta: PT Raja Grafindo Persada.

Daryanto.( 2016). Inovasi Pembelajaran Efektif. Bandung: CV Yrama Widya

Saudarwan, Danim. (2010). Profesionlisasi dan Profesi Guru. Bandung: CV Alfabeta

Moeleong, Lexy J. (2017). Metodelogi Penelitian Kualitatif. Bandung: PT Remaja Rosda Karya.

Khomariyah, Aan. (2010). Metodelogi Penelitian Kualitataif. Bandung: Alfabeta.

Sugiyono. (2015). Metode Penelitian Pendidikan (Pendekatan Kuantitatif, Kualitatif, dan $R \& D)$.

Saud, Udin Syaefudin. (2010). Pengembangan Profesi Guru. Bandung: Alfabeta. 